\title{
ANALISIS FAKTOR-FAKTOR YANG MEMPENGARUHI KEPUTUSAN MEMBELI DI ONLINE SHOP MAHASISWA JURUSAN PENDIDIKAN EKONOMI ANGKATAN TAHUN 2012
}

\author{
Oleh \\ Ni Kadek Devi Aprillia Agustini \\ Jurusan Pendidikan Ekonomi, Fakultas Ekonomi \\ Universitas Pendidikan Ganesha Singaraja, \\ Indonesia \\ e-mail: deviaprillia15.id@gmail.com
}

\begin{abstract}
ABSTRAK
Penelitian ini bertujuan untuk mengetahui (1) faktor-faktor yang mempengaruhi keputusan pembelian di online shop mahasiswa Jurusan Pendidikan Ekonomi angkatan tahun 2012 dan (2) faktor yang paling dominan mempengaruhi keputusan membeli di online shop mahasiswa Jurusan Pendidikan Ekonomi angkatan tahun 2012. Jenis penelitian ini merupakan penelitian faktorial. Populasi dalam penelitian ini adalah seluruh mahasisiwa jurusan pendidikan ekonomi angkatan tahun 2012 yang berjumlah 68 orang dan dianalisis dengan analisis faktor. Hasil penelitian menunjukkan, (1) terdapat empat faktor yang mempengaruhi keputusan membeli di online shop mahasiswa Jurusan Pendidikan Ekonomi angkatan tahun 2012, yaitu kualitas produk, kemudahan, kualitas informasi, dan kepercayaan konsumen. Besarnya variance explained faktor secara berturut-turut, yaitu kualitas produk sebesar $68,934 \%$, kemudahan sebesar $28,744 \%$, kualitas informasi sebesar $1,470 \%$, dan kepercayaan konsumen sebesar $0,853 \%$. (2) faktor yang paling dominan mempengaruhi keputusan membeli di online shop mahasiswa jurusan pendidikan ekonomi angkatan 2012, yaitu kualitas produk dengan memiliki variance explained sebesar $68,934 \%$, artinya total nilai variance explained dari kualitas produk mampu menjelaskan keputusan membeli di online shop mahasiswa Jurusan Pendidikan Ekonomi angkatan tahun 2012.
\end{abstract}

Kata kunci: keputusan, membeli, online shop

\section{ABSTRACT}

This research aims to understand (1) factors which affect the decision of transaction activity on online shop by the 2012's students of economic education and (2) the most dominant factor which affects decision of transaction activity on online shop by the 2012's students of economic education. A kind of this research is factorial research. The population of this research is all of the 2012's student members of economic education which totaled 68 people and analyzed with factorial analysis. The result of this research is showed, (1) there are four factors which affect the decision of transaction activity on online shop by the 2012's students of economic education, specifically the quality of product, the easiness, the quality of information, and the customers trust. The size of variance explained factor in order, specifically the quality of product is as much as $68,934 \%$, the easiness is as much as $28,744 \%$, the quality of information is as much as $1,470 \%$, and the customers trust is as much as $0,853 \%$. (2) The most dominant factor which affects decision of transaction activity on online shop by the 2012's students of economic education is the quality of the product which has the variance explained as much as $68,934 \%$, it means the total value of variance explained of the product's quality is able to explain the decision of transaction activity on online shop by the 2012's students of economic education.

Keyword: decision, buy, online shop 


\section{PENDAHULUAN}

Keputusan adalah pemilihan dari dua atau lebih alternatif pilihan, dengan kata lain untuk membuat keputusan harus terdapat alternatif pilihan. Sebaliknya jika konsumen tidak memiliki alternatif untuk memilih maka tidak dapat dikategorikan sebagai pengambilan keputusan. Tidak semua konsumen dalam mengambil keputusan memerlukan tingkat pencarian informasi yang sama. Jika dalam pengambilan keputusan memerlukan usaha yang besar, maka konsumen perlu meluangkan waktu untuk melalukan proses keputusan. Sebaliknya untuk pembelian yang sifatnya rutin cenderung merupakan peristiwa yang monoton dan menunjukkan berkurangnya tingkat kesenangan.

"The selection of an option from two or alternative choice". Dapat diartikan keputusan pembelian adalah suatu keputusan seseorang dimana dia memilih salah satu dari beberapa alternatif pilihan yang ada. Keputusan pembelian adalah tindakan yang dilakukan konsumen untuk melakukan pembelian sebuah produk (Schiffman and Kanuk, 2002) Oleh karena itu, pengambilan keputusan pembelian konsumen merupakan suatu proses pemilihan salah satu dari beberapa alternatif penyelesaian masalah dengan tindak lanjut yang nyata. Setelah itu konsumen dapat melakukan evaluasi pilihan dan kemudian dapat menentukan sikap yang akan diambil selanjutnya.

Keputusan membeli merupakan suatu keputusan seseorang diamana dia memilih salah satu dari beberapa alternatif pilihan yang ada dalam memenuhi kebutuhan berupa barang maupun jasa. Menurut Swastha dan Irawan (2008) bahwa : "Keputusan pembelian adalah pemahaman konsumen tentang keinginan dan kebutuhan akan suatu produk dengan menilai dari sumber-sumber yang ada dengan menetapkan tujuan pembelian serta mengidentifikasi alternatif sehingga pengambilan keputusan untuk membeli yang disertai dengan perilaku setelah melakukan pembelian". Dengan mengutamakan pelayanan yang baik maka pembeli akan memudahkan perusahaan mencapai tujuan perusahaan yaitu mencapai laba yang maksimal melalui peningkatan jumlah pembeli. Keputusan pembelian konsumen merupakan suatu proses pemilihan salah satu dari beberapa alternatif penyelesaian masalah dengan tindak lanjut yang nyata.

Keputusan untuk membeli yang diambil oleh pembeli sebenarnya merupakan kumpulan dari sejumlah keputusan (Kotler,2007). Setiap keputusan untuk membeli tersebut mempunyai suatu struktur sebanyak lima komponen, yaitu meliputi. (1) Keputusan tentang jenis produk, Dalam hal ini konsumen dapat mengambil keputusan tentang produk apa yang akan dibelinya untuk memenuhi dan memuaskan kebutuhan, (2) Keputusan tentang bentuk produk, Konsumen dapat mengambil keputusan untuk membeli suatu produk dengan bentuk tertentu sesuai dengan seleranya, (3) Keputusan tentang merek, Konsumen harus mengambil keputusan tentang merek mana yang akan dibeli karena setiap merek mempunyai perbedaanperbedaan tersendiri, (4) Keputusan tentang penjualnya, Konsumen dapat mengambil keputusan dimana produk yang dibutuhkan tersebut akan dibeli, dan (5) Keputusan tentang waktu pembelian Konsumen dapat mengambil keputusan tentang kapan dia harus melakukan pembelian. Saat ini pembelian atau keputusan membeli suatu produk tidak hanya dilakukan pembeli dengan mendatangi toko atau tempat penjualan secara langsung. Karakteristik konsumen saat ini serta peralihan sikap mereka tentang cara berbelanja secara lebih mudah murah dan efesien yaitu dengan online shopping. Dimensi untuk mengukur keputusan pembelian yang diambil oleh konsumen adalah sebagai berikut. (1) Benefit Association adalah Kriteria benefit association menyatakan bahwa konsumen menemukan manfaat dari produk yang akan dibeli dan menghubungkannya dengan 
karakteristik merek. Kriteria manfaat yang bisa diambil adalah kemudahan mengingat nama produk ketika dihadapkan dalam keputusan membeli produk. (2) Prioritas dalam membeli adalah Prioritas untuk membeli terhadap salah satu produk yang ditawarkan bisa dilakukan oleh konsumen apabila perusahaan menawarkan produk yang lebih baik dari produk pesaingnya. (3) Frekuensi pembelian adalah Ketika konsumen membeli produk tertentu dan ia merasa puas dengan kinerja produk tersebut, maka ia akan sering membeli kembali produk tersebut kapanpun.

\section{Belanja online (online shopping)} merupakan proses pembelian barang/jasa oleh konsumen ke penjual realtime, tanpa pelayan, dan melalui internet (Ollie, 2008). Toko virtual ini mengubah paradigma proses membeli barang/jasa dibatasi oleh tembok, pengecer, atau mall Agus Irwantoko (2012). Yang artinya tidak perlu harus bertemu penjual/pembeli secara langsung, tak perlu menemukan wujud 'pasar' secara fisik, namun hanya dengan menghadap layar monitor computer, dengan koneksi internet tersambung, kita dapat melakukan transaksi jual/beli secara cepat dan nyaman. Keunggulan belanja online dari pada belanja secara offline yaitu. (1) Mudah karena dapat dilakukan dimana saja \& kapan saja, melalui perangkat computer dimana saja yang terkoneksi dengan internet, termasuk dari perangkat mobile pribadi. Mudah karena tinggal masuk ke web, pilih produk, baca deskripsi produk, klik beli, pilih cara pembayaran, dan tunggu barang diantar, (2) Murah alasan lain adalah belanja lewat online lebih murah. Ini karena biaya untuk menjual produk di internet lebih murah sehingga secara fair konsumen juga berhak atas biaya yang lebih murah jika dibandingkan dengan harga di pasar offline. Bahkan bila harga barang di online sama dengan harga di offline itupun masih bisa dihitung lebih murah karena ada beberapa komponen biaya lain yang sebenarnya tidak perlu dikeluarkan seperti biaya bensin, parkir, toll, makan, dll. Jadi belanja online memang benar-benar lebih murah, (3) Praktis karena tidak perlu mendorong trolley, tidak perlu antri di kasir, dan tidak perlu marah-marah dengan layanan SPG yang lama dan tidak memuaskan. Belanja online bisa dilakukan dimana saja, kapan saja, dengan alamat pengiriman yang boleh ditentukan sendiri misalnya untuk ke rumah sendiri, ke kantor atau ke rumah teman atau saudara misalnya untuk kado. Tidak ada model belanja lain yang bisa menandingi kepraktisan model belanja seperti ini sejauh ini, (4) Efisien karena Konsumen tidak perlu berlama-lama menghabiskan waktu mencari produk yang di butuhkan. Waktu menjadi lebih efisien dari pada harus berjam-jam menembus kemacetan lalu lintas. E-commerce yang saat ini hadir menjamur baik dalam skala rumahan, toko online individu, maupun e-commerce besar, tentu saja semua untuk melayani kita supaya hidup lebih efisien, dan (5) Modern adalah solusi berbelanja lewat online adalah gaya hidup manusia modern yang menyukai kepercayaan, kepraktisan, efisien, kemudahan, dan memanfaatkan kemajuan teknologi informasi dan komputer. Konsumen seperti ini umumnya adalah kelas menengah dan atas tidak peduli siapapun mereka orangtua, ibu rumah tangga, karyawan, pelajar /mahasiswa, profesional, atau pengusaha, adalah orang-orang dengan pemikiran modern dan percaya bahwa belanja tidak harus bertatap muka dengan penjual atau melihat barang secara langsung karena percaya bahwa integritas adalah sesuatu yang harus dijunjung tinggi.

Belanja online juga mempunyai kelemahan-kelemahan, yaitu, (1) Kualitas barang yang diinginkan kadangkadang berbeda kualitasnya dengan yang tercantum di website, (2) Rentan Penipuan Beberapa Jenis Penipuan yang sering terjadi dalam kasus Pembelian atau berbelanja secara online adalah sebagai berikut : (a) Phising merupakan Pembajakan lewat situs tipuan, membuat web yang mirip dengan web lainnya dengan maksud untuk menipu. (b) Produk palsu, Menjual 
produk palsu yang mungkin didapatkan dari sumber yang tidak dapat dipercaya dan bahkan produk tersebut tidak dapat digunakan sama sekali atau produk tersebut tidak memenuhi standar yang telah ditentukan pemerintah, (c) Produk tidak dikirim, Sering terjadi setelah pembeli mengirimkan dana pembayarannya namun produk tak pernah diterima pembeli. Penipuan jenis ini paling sering terjadi pada instant payment seperti metode pembayaran bank transfer.(3) Rentan rusak atau pecah karena media pengiriman adalah pos, (4) Rentan aksi pemboboloan rekening karena pembayaran dilakukan melalui Internet, (5) Marak aksi spamming karena setelah pembeli melakukan registrasi, penjual cenderung selalu mengirimkan katalog online melalui email pembeli dan hal ini cukup mengganggu privacy.

Online shop itu sendiri adalah proses pembelian barang dan jasa melalui internet dimana penjual dan pembeli tidak berhubungan secara langsung atau tidak bertemu dan tidak melakukan kontak secara fisik, dan dimana barang yang diperjual belikan hanya ditawarkan melalui gambar yang ada dalam suatu website atau toko online kemudian pembayaran dilakukan melalui transfer ke rekening bank yang bersangkutan, Setelah proses pembayaran diterima, kewajiban penjual adalah mengirim barang pesanan pembeli ke alamat tujuan (Rifqi Adi Nugroho, 2013). Hal ini sejalan dengan pendapat Miklos ( 2002) yang menyatakan bisnis online disebut juga dengan e-commerce. E-commerce adalah sebuah konsep baru dalam proses jual beli barang atau jasa secara fisik atau digital dari satu lokasi ke lokasi lain. Artinya bahwa transaksi jual beli dapat dilakukan secara digital melalui internet meskipun penjual dan pembeli tidak bertemu secara langsung. Hal tersebut mengakibatkan perubahan sistem jual beli dan mengubah paradigm konsumen dalam melakukan transaksi jual beli yang berawal dari teknologi lama konvensional menjadi teknologi modern atau adanya perubahan dari berbelanja ke pasar tradisional menjadi berbelanja online (online shop).

Online shop adalah salah satu perkembangan teknologi yang semakin modern, serba canggih yang membuat segala sesuatu pun menjadi lebih cepat dan instan. Banyak masyarakat saat ini lebih memilih online shop karena online shop itu sendiri dirasakan lebih mudah, murah, menguntungkan dan efesien. Ketertarikan masyarakat yang tinggi terhadap online shop mengakibatkan banyak online shop yang bermunculan mulai dari online shop yang jujur, tidak jujur, ataupun dari fiktif maupun nyata bahkan sampai toko online penipuan.

Mahasiswa Jurusan Pendidikan

Ekonomi angkatan tahun 2012 berjumlah 68 orang. Mahasiswa dan mahasiswi menggunakan online shop untuk memnuhi kebutuhan mereka. Kebutuhan mahasiswi dalam menggunakan jasa online shop untuk membeli barang-barang seperti : pakaian tas, sepatu, dan kebutuhan pribadi lainya. Dan mahasiswa dalam menggunakan jasa online shop dalam memenuhi kebutuhan pada pemenuhan hobi seperti pembelian alat olahraga, pakaian, tas yang dibutuhkan. Dari hasil penyebaran kuesioner kepada mahasiswa Jurusan Pendidikan Ekonomi angkatan tahun 2012 yang berjumlah 68 mahasiswa, 5 orang tidak pernah belanja online, 18 orang tidak pernah kecewa dalam belanja online , 45 orang pernah kecewa dalam belanja online tetapi mereka tetap berbelanja online.

Dari latar belakang yang telah ditentukan, maka dapat dirumuskan masalah sebagai berikut, (1) faktorfaktor apa saja yang mempengaruhi keputusan membeli di online shop mahasiswa Jurusan Pendidikan Ekonomi angkatan tahun 2012, (2) faktor mana yang paling dominan mempengaruhi keputusan membeli di online shop mahasiswa Jurusan Pendidikan Ekonomi angkatan tahun 2012. Meninjau dari permasalahan yang ada maka tujuan penelitian ini adalah, (a) untuk mengetahui faktor-faktor yang mempengaruhi keputusan membeli di 
online shop mahasiswa Jurusan Pendidikan Ekonomi angkatan tahun 2012, (b) untuk mengetahui faktor yang paling dominan yang mempengaruhi keputusan membeli di online shop mahasiswa Jurusan Pendidikan Ekonomi angkatan tahun 2012.

Manfaat dari penelitian ini yaitu, (1) Manfaat teoritis, hasil penelitian ini diharapkan dapat memberikan sumbangan pengembangan ilmu ekonomi dalam bidang manajemen pemasaran, khususnya dalam strategi pemasaran online shop, (2) manfaat praktis, (a) hasil penelitian ini diharapkan dapat memberikan masukan bagi mahasiswa untuk pertimbangan dalam membeli produk-produk yang ditawarkan oleh online shop sehingga mahasiswa terhindar dari penipuan online shop, (b) hasil penelitian ini diharapkan dapat memberikan masukan bagi pemilik online shop agar dapat mengembangkan inovasi serta keunggulan kompetitif dalam bersaing sehingga dapat meningkatkan penjualan.

\section{METODE}

Populasi pada penelitian ini adalah mahasiswa Jurusan Pendidikan Ekonomi angkatan tahun 2012 dengan jumlah sebanyak 68 mahasiswa. Mengingat jumlah populasi yang sedikit, maka akan diambil seluruhnya untuk dijadikan sampel yaitu sebanyak 45 mahasiswa. Pengumpulan data dilakukan dengan metode kuesioner atau angket. Kuesioner dalam penelitian ini disebarkan kepada 45 responden
Jurnal Pendidikan Ekonomi Undiksha

Volume 9 No.1 Tahun: 2017

yang merupakan seluruh mahasiswa Jurusan Pendidikan Ekonomi angkatan tahun 2012. jenisnya, data yang digunakan dalam penelitian ini adalah data kualitatif. Data kualitatif dalam penelitian ini berupa data yang diperoleh dari responden (mahasiswa) Jurusan Pendidikan Ekonomi angkatan tahun 2012. Sumber data yang digunakan dalam penelitian ini yaitu, data primer, diperoleh dari responden secara langsung melalui kuesioner yang diisi sendiri oleh responden yang dijadikan sampel penelitian. Analisis data yang digunakan penelitian ini adalah analisis faktor. pengujian hipotesis dilakukan dengan menggunakan Statistical Program Social Science (SPSS) 16.0 for Windows dengan menggunakan factor analysis.

\section{HASIL DAN PEMBAHASAN Hasil}

Data yang berhasil dikumpulkan dari kuesioner yang disebarkan dan setelah diolah dengan SPSS 16.0 for Windows menunjukkan faktor-faktor yang mempengaruhi keputusan membeli di online shop mahasiswa Jurusan Pendidikan Ekonomi angkatan tahun 2012 dapat dijelaskan oleh persentase dari masing-masing faktor. Nilai total Variance Explained digunakan untuk mengetahui persentase dari empat faktor yang dianalisis. Hasil analisis faktor melalui SPSS menunjukkan persentase dari masing-masing faktor dapat dilihat pada Tabel 1.

\section{TABEL.1 Total Variance Explained}

\begin{tabular}{|c|c|c|c|c|c|c|c|c|c|}
\hline \multirow[b]{2}{*}{$\begin{array}{l}\text { Comp } \\
\text { onent }\end{array}$} & \multicolumn{3}{|c|}{ Initial Eigenvalues } & \multicolumn{3}{|c|}{$\begin{array}{l}\text { Extraction Sums of } \\
\text { Squared Loadings }\end{array}$} & \multicolumn{3}{|c|}{$\begin{array}{c}\text { Rotation Sums of Squared } \\
\text { Loadings }\end{array}$} \\
\hline & Total & $\begin{array}{c}\% \text { of } \\
\text { Variance }\end{array}$ & $\begin{array}{l}\text { Cumulati } \\
\text { ve } \%\end{array}$ & Total & $\begin{array}{c}\% \text { of } \\
\text { Variance }\end{array}$ & $\begin{array}{l}\text { Cumulat } \\
\text { ive } \%\end{array}$ & Total & $\begin{array}{c}\% \text { of } \\
\text { Variance }\end{array}$ & $\begin{array}{l}\text { Cumulati } \\
\text { ve } \%\end{array}$ \\
\hline 1 & 2.757 & 68.934 & 68.934 & 2.757 & 68.934 & 68.934 & 1.982 & 49.552 & 49.552 \\
\hline 2 & 1.150 & 28.744 & 97.677 & 1.150 & 28.744 & 97.677 & 1.925 & 48.125 & 97.677 \\
\hline 3 & .059 & 1.470 & 99.147 & & & & & & \\
\hline 4 & .034 & .853 & 100.000 & & & & & & \\
\hline
\end{tabular}


Berdasarkan tabel 1 dapat dilihat bahwa (1) faktor kualitas produk memiliki eigenvalue sebesar 2,757 dengan nilai varian sebesar $68,934 \%$, (2) faktor kemudahan memiliki eigenvalue sebesar 1,150 dengan nilai varian sebesar $28,744 \%$, (3) faktor kualitas informasi memiliki eigenvalue sebesar 0,059 dengan nilai varian sebesar 1,470\%, dan (4) faktor kepercayaan konsumen memiliki eigenvalue sebesar 0,034 dengan nilai varian sebesar $0,853 \%$.

Untuk menjelaskan keputusan membeli di online shop mahasisiwa Jurusan Pendidikan Ekonomi angkatan tahun 2012, dapat dilakukan dengan ekstraksi faktor. Ekstraksi faktor dapat dijelaskan oleh total persentase dari masing-masing faktor utama. Faktorfaktor utama tersebut adalah faktor kualitas produk dan kemudahan yang memiliki nilai parameter eigenvalue $>1$. Untuk mengetahui distribusi dimensidimensi yang belum dirotasi kedalam faktor yang telah terbentuk maka dapat dilihat pada output SPSS 16.0 (Rotated Component Matrix). Faktor yang mampu menjelaskan keputusan membeli di online shop mahasiswa Jurusan Pendidikan Ekonomi angkatan tahun 2012, dapat dilihat pada Tabel 2.

Tabel 2. Faktor yang Menjelaskan Membeli di Online Shop Mahasiswa Jurusan Pendidikan Ekonomi Angkatan Tahun 2012

\begin{tabular}{lccc}
\hline \multicolumn{1}{c}{ Faktor } & Eigenvalue & Varianced Explained (\%) & Faktor Loading \\
\cline { 2 - 2 } \cline { 3 - 4 } Kualitas Produk & 2,757 & 68,934 & .975 \\
Kemudahan & 1,150 & 28,744 & .958 \\
Kualitas Informasi & 0,059 & 1,470 & .982 \\
$\begin{array}{l}\text { Kepercayaan } \\
\text { Konsumen }\end{array}$ & 0,034 & 0,853 & .935 \\
\hline
\end{tabular}

Berdasarkan dari Tabel 2 di atas, dapat dijelaskan bahwa faktor yang memiliki eigenvalue $>1$ adalah fakor kualitas produk dan kemudahan, total nilai variance explained dari kedua faktor keseluruhan mampu menjelaskan sebesar 97,677\%, dengan demikian $97,677 \%$ dari seluruh faktor yang ada, dapat dijelaskan oleh kedua faktor yang terbentuk. Kualitas produk memiliki variance explained $68,934 \%$, artinya bahwa kualitas produk mampu mempengaruhi keputusan membeli di

online shop sebesar 68,934\%.

Kemudahan memiliki variance explained $28,744 \%$ artinya kemudahan mempengaruhi keputusan mmbeli di online shop sebesar $28,744 \%$.

Menentukan nama faktor yang telah terbentuk untuk masing-masing faktor bersifat subjektif, kadangkala variabel yang memiliki nilai faktor loading tertinggi digunakan untuk memberi nama faktor. Untuk melihat nilai faktor loading dapat dilihat pada Tabel 3.

Tabel 3. Rotated Component Matrix

\begin{tabular}{ccc}
\hline & \multicolumn{2}{c}{ Component } \\
\hline & 1 & 2 \\
\hline Kepercayaan konsumen & .975 & .163 \\
\hline Kualitas Informasi & .958 & .245 \\
\hline Kualitas Produk & .115 & .982 \\
\hline Kemudahan & .317 & .935 \\
\hline
\end{tabular}


Bedasarkan Tabel 3 di atas, faktor yang mempengaruhi keputusan membeli di online shop dapat dikelompokkan menjadi 2 (dua) faktor. Masing-masing kelompok faktor tersebut memiliki faktor loading tertinggi di setiap komponen yaitu faktor satu terbentuk dari faktor Faktor 1 (satu) terbentuk dari faktor kepercayaan konsumen dengan faktor loading sebesar 0,975, dan faktor kualitas informasi dengan faktor loading sebesar 0,958. Faktor 2 (dua) terbentuk dari faktor kualitas produk dengan faktor loading sebesar 0,982, faktor kemudahan dengan faktor loading 0,935 .

Kemudian untuk menentukan dimensi faktor yang paling dominan mempengaruhi keputusan membeli di online shop mahaiswa jurusan pendidikan ekonomi angkatan tahun 2012, digunakan parameter koefesien varimax atau mendekati 1 atau mendekati -1 . Nilai yang mendekati 1 diawali oleh nilai 0,50 sedangkan nilai yang mendekati -1 diawali oleh -0,50. Secara lebih rinci hasil ringkasan rotasi dari matriks faktor memuat nilai varimax rotation, dapat dilihat pada tabel 4 .

Tabel 4. Matriks Rotasi Hasil Anallisis Faktor

\begin{tabular}{ccc}
\hline Dimensi atau faktor keputusan membeli & \multicolumn{2}{c}{ Varimax Rotation (\%) } \\
\cline { 2 - 3 } & $(1)$ & $(2)$ \\
\hline Kualitas Produk & 68,934 & - \\
\hline Kemudahan & - & 28,744 \\
\hline
\end{tabular}

Berdasarkan tabel 4, maka faktor yang paling dominan mempengaruhi keputusan membeli di online shop mahasiswa jurusan pendidikan ekonomi angkatan 2012 adalah faktor kualitas produk dengan nilai varimax rotation $68,934 \%$. Artinya kejelasan dari dimensi atau faktor keputusan membeli di online shop adalah kualitas produk yang paling mendominasi sebesar $68,934 \%$.

\section{Pembahasan}

Keputusan membeli di Online Shop mahasiswa Jurusan Pendidikan Ekonomi angkatan 2012 dipengaruhi oleh faktor kualitas produk, kemudahan, kualitas informasi, dan kepercayaan konsumen. Hal ini, sesuai dengan teori yang dinyatakan oleh Rangkuti dalam Khotler (2009), bahwa faktor yang mempengaruhi keputusan membeli di online shop adalah kualitas produk, kemudahan, kualitas informasi, dan kepercayaan konsumen. Untuk menjelaskan hal yang mempengaruhi keputusan membeli di online shop bagi mahasiswa Jurusan Pendidikan Ekonomi angkatan tahun 2012, dapat dilihat dari faktor-faktor yang memiliki eigenvalue > 1 faktor kualitas produk dan faktor kemudahan. Faktor kualitas produk dan kemudahan merupakan faktor dominan yang mempengaruhi keputusan membeli di online shop bagi mahasiswa Jurusan Pendidikan Ekonomi angkatan 2012. Faktor kualitas produk merupakan faktor yang paling dominan mempengaruhi keputusan membeli mahasiswa Jurusan Pendidikan Ekonomi angkatan tahun 2012. Faktor ini paling dominan dibandingkan faktor-faktor yang lain disebabkan karena kualitas produk adalah salah faktor utama kriteria pilihan konsumen dalam melakukan pembelian di online shop. Kualitas membuat suatu perusahaan atau organisasi yang menghasilkan produk dapat dikenal dan dipercaya masyarakat luas. Kualitas produk dapat dikatakan sebagai kemampuan suatu produk untuk melaksanakan fungsinya seperti kesesuaian yang berarti jika semakin besar frekuensi pemakaian konsumen terhadap produk maka semakin besar pula daya tahan produk., bentuk produk, desain produk, dan gaya atau penampilan produk yang dapat mempengaruhi kinerja jangka panjang suatu unit bisnis. Hasil penelitian ini sejalan dengan teori Rangkuti (2009), kualitas produk meliputi conformance 
(kesesuaian), durability (ketahanan), reliability (keandalan), form (bentuk), design (desain), dan style (penampilan produk). Keenam indikator tersebut adalah hal penting dalam menentukan keputusan membeli di online shop.

Kemudahan dalam penggunaan adalah salah satu hal yang menjadi pertimbangan bagi pembeli online shop. Trend jual beli saat ini semakin marak dengan kegiatan online yang tidak merepotkan penggunanya. Kemudahan dalam mempelajari, menggunakan, pengoprasian sesuai dengan apa yang diinginkan dan penggunaanya yang fleksibel merupakan alasan konsumen untuk memilih dalam belanja online. Kelebihan-kelebihan dari Online Shop inilah yang menyebabkan bisnis online menjadi trend. Hasil penelitian ini sejalan dengan teori Rangkuti (2009), alasan konsumen lebih memilih belanja online karena kemudahan yang di berikan kepada konsumen .

\section{SIMPULAN DAN SARAN Simpulan}

Berdasarkan hasil analisis data dan pembahasan, maka dapat ditarik simpulan yaitu, (1) faktor-faktor yang mempengaruhi keputusan membeli di online shop mahasiswa Jurusan Pendidikan Ekonomi angkatan tahun 2012 adalah, (a) faktor kualitas produk dengan nilai varian sebesar $68,934 \%$, (b) kemudahan dengan nilai varian sebesar $28.744 \%$, (c) kualitas informasi dengan nilai varian sebesar $1.470 \%$, dan (d) kepercayaan konsumen dengan nilai varian sebesar $0,853 \%$. (2) faktor yang paling dominan mempengaruhi keputusan membeli di online shop mahasiswa Jurusan Pendidikan Ekonomi angkatan tahun 2012 adalah kualitas produk dengan nilai varimax rotation $68,934 \%$.

\section{SARAN}

Berdasarkan kesimpulan di atas, maka dapat diajukan beberapa saran yaitu, (1) Bagi mahasiswa Jurusan Pendidikan
Jurnal Pendidikan Ekonomi Undiksha

Volume 9 No.1 Tahun: 2017

Ekonomi Universitas Pendidikan

Ganesha, hendaknya lebih mempertimbangkan kembali dalam melakukan pembelian pada online shop agar tidak mudah tertipu dalam melakukan pembelian, (2) Bagi pemilik online Shop lebih kreatif dan inovatif dalam menjalankan bisnis online agar mampu menarik lebih banyak customer baru untuk meningkatkan motivasi belanja online, sebab konsep ecommerce atau perdagangan elektronik lewat internet ini menjadi pusat perhatian banyak orang yang memberikan kemudahan sistem berbelanja, (3) Bagi peneliti lain diharapkan menjadi acuan penelitian berikutnya yang lebih luas, mendalam kajianya dan menambah ilmu pengetahuan tentang keputusan membeli.

\section{DAFT AR PUSTAKA}

Agus Irwantoko, Fatchur Rohman, dan Noermijati, 2009. "Pengaruh Kualitas Produk dan Strategi Harga terhadap Kepuasan Pelanggan, dan Pengaruhnya pada Terbentuknya Word-OfMouth di Perumahan Madani Group Jabodetabek", Jurnal Aplikasi Manajemen, Volume 11, Nomer 1, Maret 2011.

Arikunto, Suharsini. 2002. Dasar-Dasar Evaluasi Pendidikan. Jakarta : Bumi AksaraC. Laudon, Kenneth \& P. Laudon, Jane. 2005. Sistem Informasi Manajemen Mengelola Perusahaan Digital. Edisi 8. Yogyakarta: Andi Offset.

Chin, W Wynne \& Todd Peter. 1995. On The use Usefullness,ease of use of structural equation Modeling in MIS Research: A note of Caution. Management Information System Quarterly, 21(3).

Davis, et. al. 1989. User Acceptance of Information Technology: System Characteristics, User Perception and Behavioral 
p-ISSN : 2599-1418

e-ISSN : 2599-1426

Impacts International Journal of Man-Machine Studies. 38 (3): 475-487.

Durianto, D. dan C. Liana, 2004. "Analisis Efektivitas Iklan Televisi Softener Soft \& Fresh di Jakarta dan Sekitarnya dengan Menggunakan Decision Model". Jurnal Ekonomi Perusahaan, 11 (1): 35-55.

Eka, dan Rita, 2001, "Periklanan Yang Efektif", Jurnal Ekonomi Perusahaan, Vol. 8, No. 2

Ghozali, Iman. 2006. Aplikasi Analisis Multivariate Dengan Program SPSS. Cetakan IV. Semarang: Badan Penerbit Universitas Diponegoro.

Hatana. Samuel, 2006. "Dampak Respon Emosi Terhadap Kecendrungan Prilaku Pembelian Inulsif Konsumen Online dengan Sumberdaya yang dikeluarkan dan Orientasi Belanja sebagai Variabel Moderasi". Jurnal Manajemen Kewirausahaan. Vol. 18. No.2

Umar. Husein .2006. Prosedur Penelitian Suatu Pendekatan Praktik. Jakarta: RinekaCipta.

Kotler, P dan Gary Armstrong. 2007. Prinsip-prinsip Pemasaran. Edisi Ke-12 Jilid 1. Jakarta : Erlangga.

\section{Dasar-dasar} Pemasaran. Jakarta: PT Indeks Gramedia Group.

Mc Leod, Raymond. 2008. Sistem Informasi Manajemen Studi Sistem Informasi Berbasis Komputer. Jilid II. Jakarta. PT. Prenhallindo.

Mondry. 2008. Pemahaman Teori dan Praktik Jurnalistik. Bogor Selatan: Ghalia Indonesia.
Jurnal Pendidikan Ekonomi Undiksha

Volume 9 No.1 Tahun: 2017

Miklos. 2002. Mengenal E-Commerce. Jakarta: Elex Media

Komputindo

Ollie. 2008. Membuat Toko Online dengan Multiply. Jakarta. Mediakita.

Rangkuti, F., 2009. Strategi Promosi yang Kreatif dan Analisis Kasus Integrated Marketing Communication. Jakarta: PT Gramedia Pustaka Utama.

Rianto. 2005. Sistem Informasi Penjualan PHP dan MySQL. Yogyakarta : Penerbit Gava Media.

Rifqi, Nugroho. 2013. Analisis Faktorfaktor yang Mempengaruhi Minat Beli Konsumen terhadap Layanan Internet Banking Mandiri. Skripsi (tidak diterbitkan): Universitas Diponogoro: Semarang.

Schiffman, L.G. and Kanuk, L.L. 2002. Consumer Behaviour, 7th ed. New Jersey: Prentice-Hall.

Siregar. 2010. Pemasaran Strategik, Graha Ilmu. Yogyakarta.

Siregar, Syofian. 2011. Statistik Deskriptif untuk Penelitian. Jakarta: PT Rajagrafindo Persada.

Sugiyono. 2009. Metodologi Penelitian Bisnis. Bandung: CV Alfabeta.

. 2005. Metode Penelitian Pendidikan (Pendekatan Kuantitatif, Kualitatif, dan R\&D). Bandung: ALFABETA.

Suliyanto. 2005. Analisis Data Dalam Aplikasi Pemasaran. Bogor: Galia Indonesia.

Sutisna. 2001. Prilaku Konsumen dan Komunikasi Pemasaran. 
Bandung: PT Remaja

Rosdakarya.

2003. Langkah-langkah Menjadi Webmaster. Jakarta : Penerbit Mediakita.

Swasta dan Handoko. 2008. Manajemen

Pemasaran

Modern.

Yogyakarta: Liberty.

Swasta dan Irawan. 2008. Manajemen

Pemasaran Modern.

Yogyakarta: Liberty

Ujang Sumarwan. 2004. Perilaku Konsumen Teori dan Penerapannya Dalam Pemasaran, Bogor, Ghalia Indonesia.

Wong. Joni. 2010. , Elex Media Komputindo, Jakarta. 